\title{
Development of a Tool for Determining Moral Distress among Teachers in Basic Schools
}

\author{
MARKÉTA VÁCHOVÁ
}

\begin{abstract}
Morality can be linked with education in the broadest sense in connection with the various topics associated with this phenomenon. This manuscript focuses on the decision-making processes in contemporary teachers' work that are connected with morally dilemmatic situations. The text deals with the problematics of moral dilemmas in teachers' work. It specifically focuses on the situation in Czech basic education.

The second half of the $20^{\text {th }}$ century was characterized by an effort to professionalize various occupations, among them also teaching. If we are to accept the rather problematic concept of the professionalization of teaching, it is necessary to (constantly) fulfil the attributes of the profession. These include professional autonomy. Its boundary is disputed and relativized. Social pressure on schools, manager-like styles of running schools, and the increasing influence of parents on schools pose risks of improper interventions into professional decision making in teachers' work.

In his work a teacher is often confronted with situations which require him to make a professional moral choice. These are conflict situations that require the teacher to make a fundamental decision and, depending on his professional and personal characteristics, they have significant consequences for his subsequent work. Within his professional field the teacher then has to give in to social pressure and to adopt his approach to something that he does not identify with, or he has to speak out against this pressure and confront the situation.

In these situations in which the teacher has to act against his own convictions and gives in to pressure from his environment, the culture of his own institution, or his colleagues and parents, the long-term effect and constant presence of these dilemmas may lead to him suffering from professional moral distress. It is possible to assume that the emergence of professional moral distress is also dependent on the individual characteristics of each teacher. These include, for example, the length of his professional career in the institution and his experience or personal characteristics.

As Mareś (2017a) states, so far only scholars from abroad have dealt with the theoretical identification and diagnostics of moral distress. This manuscript declares that the prevailing sources of professional dilemmas among teachers in basic schools come from the management, parents, colleagues, and increasing (unsolvable) demands from education policy.
\end{abstract}

Keywords: teacher, moral distress, professional morally dilemmatic situations, questionnaire. 


\section{INTRODUCTION}

Contemporary society is termed postmodern. An explicit emphasis is put on individuality, originality, and plurality of opinions. What was previously considered to be clear and desirable is now denied and demolished. Ethical and moral values are also demolished. In the teaching profession, in which no ethical codex has been developed so far, the teacher has no external support and therefore faces morally dilemmatic situations in which the whole responsibility and uncertainty rests on him. These moral dilemmas may lead to the emergence of moral distress.

The concept of moral distress has started to appeared in the Czech Republic as a completely new and unknown term. However, this phenomenon has existed not only in the teaching profession (and also elsewhere) since its beginning. Moral distress is a negative stress that emerges from morally dilemmatic situations. A person who works with people and whose goal is the development of human potential is logically forced to make ethical and moral choices. Therefore, there is a probability that moral distress may emerge in this type of work. Eustress is a positive stress, which pushes people to higher performance and is motivating. Distress, on the other hand, is a negative stress and a burden for people. It is hard to overcome this type of stress. It holds us back, discourages us, and demotivates us, and it may even be destructive and endanger our health (Almeida, 2013).
In recent years, the Czech Republic has had to deal with the problematics of missing teachers in schools. The way to acquire qualified and motivated people for schools is thought to be primarily by increasing salaries. However, there is little awareness about what complicates the work of a teacher and about what difficulties teachers have to deal with. One of the problematic areas may be the increasing necessity to deal with morally dilemmatic situations. Therefore, I decided to learn more about the areas in which these situations occur and whether they actually do occur.

\section{FroM MORAL DILEMMAS}

\section{TO MORAL DISTRESS}

There are many definitions of moral distress, especially in the medical environment. For the sake of comparison I state here three definitions, which have evolved over time and which are, in my opinion, the most accurate. Each definition of moral distress comes from a situation which was morally dilemmatic for a particular individual.

The first to state the definition of moral distress was the American scholar Andrew Jameton in 1984: "Moral distress emerges in the situations in which an individual knows what is right to do, but (institutional) obstacles make it almost impossible to act in the right way (conscience)." (Jameton, 1984, p. 6). Acting in the right way could be interpreted as acting in accordance with the conscience of a particular individual. As there is no 
universal truth and good, and acting in the right way means different things for each individual, it is the conscience that forms the correct action for the majority of people.

Corley (2002) describes moral distress from the perspective of the experience of an individual who is put in front of that situation: "Moral distress is a state of a painful psychological disbalance, which causes suffering to an individual. An individual experiences this distress when he accepts the moral decision, but after that he does not act in the right way, because either real or subjectively perceived (institutional) obstacles block the way." (Corley, 2002, p. 639).

The third definition appeared in 2013 and the authors are Monica Frances Crane, Piers Bayl-Smith, and John Cartmill: "It is an experience of such a psychic distress that is a result of the committed participation of an individual on a particular decision or action (or failure that an individual won't be able to avoid this action or decision). It is such a decision or action that already crossed the boundaries of the moral or ethical conviction that an individual personally holds." (Crane, Bayl-Smith, \& Cartmill, 2013, p. 6).

The above-mentioned definitions of moral distress were formulated over a time period of 29 years. However, their substance remains the same. Each definition looks at moral distress from a different perspective, but the common ground is that the right action in a particular situation is interrupted or made impossible by external influences such as an institution or a human factor (colleagues, clients, managers, etc.).

Moral distress thus emerges in situations that are morally dilemmatic, and an individual has to decide whether he wants to act by himself or to give in to the pressure imposed by his surroundings. Morally dilemmatic situations do not necessarily have to cause moral distress. Each individual has his own level of sensitivity. The perception and acknowledgement of these situations is very subjective. The emergence of moral distress certainly depends on the length of one's practice, age, sex, and mental toughness. Moral distress is also influenced by the intensity and frequency of moral dilemmas in the work of an individual. If a person often faces morally dilemmatic situations, it is logical that moral distress may emerge more easily. There is also what has been termed 'moral residue' (Mareš, 2017b), which means that a person is not able to cope with his bad decision in a particular situation, or with the fact that he participated in something that he disagreed with. $\mathrm{He}$ may carry these situations for his whole life. It is a betrayal of one's own principles and coping with that (Webster \& Bayliss, 2000, in Mareš, 2017a).

\section{Previous Research \\ ON MORAL DISTRESS}

The research on moral distress among the teachers is not yet widespread. Moral distress was investigated in northern countries by using interviews (Mareš, 
2017b). Independent schools in Australia and in the USA dealt with ethical dilemmas of the principals of these schools (Cranston, Ehrich, \& Kimber, 2006). It turned out that what was most problematic was the relations between principals and their employees who do not do their job in the right way, and also between principals and problematic students who do not act appropriately or have very sensitive issues in their families, about which the school knows, but is not sure how to solve them without causing even greater harm to the students. These authors also mention that a person in a morally dilemmatic situation may face not only a decision involving choosing between right or wrong, but also between choosing between wrong and wrong, or choosing between right and right, or that more than two possible choices exist.

However, so far quantitative research on moral distress exists only among healthcare professionals. The tool for measuring it is called the Moral Distress Scale.

In 2017a, Mareš pointed out this phenomenon and emphasized the importance of investigating it in the teaching profession too. In his article, he compares the medical and teaching environments and mentions similarities with respect to the substance of goals in both professions. He also mentions similarities in their work with clients, in their work relations, and also in the social climate. It is logical that the occurrence of moral dilemmas will be more intense in the helping professions than in any other profession.

Teachers, healthcare professionals, and social workers have one thing in common. They are working groups that are known as semi-professions (therefore incomplete professions). The first to come up with this term was Amitai Etzioni in 1969, who, on the basis of three reasons, labelled teachers, nurses, and social workers as an incomplete profession, half-profession, or semi-profession. His main reasons were: working in big bureaucratic and hierarchized organizations, a large number of members, and a large number of women that perform the work. Many authors have commented on this theory over the years and have tried to demarcate the features of a 'real' profession. They have also discussed whether teaching meets the criteria or not (Hargreaves, 2000; Huberman, 1978; Štech, 2008). One of the reasons why the teaching profession is called a semi-profession, half-profession, or an incomplete profession is the low level of autonomy in teaching work. External factors interfere with the teacher's work. Teachers usually have scant competence to decide on matters that are directly related to the execution of their profession. Because of these external interventions and changes, teachers often work in circumstances that they do not create and with which they may not identify themselves. In this particular setting in the workplace, situations may appear that confront the teacher with a morally dilemmatic choice. 
I accepted the challenge that Mareš presented and I decided to identify and measure moral distress among teachers by using a questionnaire that I created. The target group for measuring moral distress was teachers working in basic schools in the Czech Republic. In my opinion, there is a very high probability of the occurrence of moral distress in this group of teachers. There are often external interventions into the work of teachers in basic schools and kindergartens, and their working conditions often change (Vašutová, 2004; Helus \& Lukášová, 2012). These teachers have scant autonomy in their work, unlike academics and high school teachers. At this stage of education it is the youngest pupils who are educated and receive the basis of education and upbringing that continues their family upbringing. School represents the second stage of socialization in human life. Teachers have to deal with great responsibility, expectations, and pressure from society and parents. Teachers working in basic schools do not have an option to exclude a pupil from the school. They have to work with what they have. Another major source of moral dilemmas and possible moral distress could be inclusive education. Teachers usually do not react to it with enthusiasm and they express concerns about their ability to realize it successfully (Váchová, 2017). Another source could be the curriculum reform, which led to a vivid debate not just among primary and secondary school teachers, but also among academics (Janík, 2013; Straková, 2007).

\section{Process of The CREATION OF THE QUESTIONNAIRE ON MORAL DISTRESS AMONG PRIMARY AND} SECONDARY SCHOOL TEACHERS

The first step was to approach Ann Baile Hamric, the author of the MDS questionnaire, which measures moral distress among nurses. I asked her to send me her questionnaire. It consists of 21 morally dilemmatic situations. First, the respondent is acquainted with the concept of moral distress (moral load) and asked to respond to each situation by using a Likert scale from 0 to 4 , where 0 has the lowest value and 4 has the highest value. The respondent states the frequency (how often he encounters the situation in his work) and the level of disturbance (to what extent the situation annoys him or disturbs him). At the end of the questionnaire there is a blank space where the respondent may add other morally dilemmatic situations that he encountered in his work and considers important and essential. At the very end of the questionnaire there is a question on whether the respondent has ever considered quitting his profession or whether he is considering quitting his profession after filling in this questionnaire.

The situations contain moral dilemmas in the work of a nurse working with her client (patient), working with her boss, working with the client's (patient's) family, and working with her colleagues, and dilemmas caused by orders from the insurance companies or society. 
With the author's permission I wanted to translate the questionnaire and adjust it to the Czech educational environment of teachers in primary and secondary schools. After translating the questionnaire, I found out that the adaptation of this research tool would not be possible. The morally dilemmatic situations presented in the questionnaire were purely from the medical environment. They were concerned with medicaments, death, insurance companies, etc. It was not possible to generalize them and adapt them to a different environment.

Therefore, I decided to create a brand new questionnaire, which would be inspired by the MDS research tool only with regard to its structure.

In order to find out the morally dilemmatic situations in teachers' work I used a qualitative approach and the method of semi-structured in-depth interviews. I conducted interviews with 20 teachers working in primary and secondary schools. They were from different regions (the South Bohemia Region, Vysočina Region, and Central Bohemia Region, Prague, the South Moravia Region, and the Plzen Region), different types of schools (basic schools in small towns with fewer than 10,000 inhabitants, in larger towns with between 10,000 and 50,000 inhabitants, and in cities with over 50,000 inhabitants), and with different lengths of practice and experience (from beginners to experienced teachers), and the group included both men and women. The interviews lasted between 30 and 60 minutes and were recorded on a dictaphone, always with the permission of the teacher. I used four questions from the article on the moral distress of school psychologists written by Mareš (2017a). I asked the teachers about the ethical and morally dilemmatic situations in their work and in the work of their colleagues. The questions were as follows: 1. Describe a situation that happened to you and that represented an ethical problem/ challenge/dilemma in your work; 2 . Describe a situation that happened to your colleagues in their work and that represented an ethical problem/challenge/ dilemma in their work; 3. Name three situations in which you violated your professional ethical boundaries; 4. Name three difficult ethical situations that you experienced in your work.

I asked these questions during the interviews. After conducting two interviews, I decided to send the questions to the teachers before the interviews, so that they had time to think about them. As a matter of fact, the 'real' interviews were very demanding for the teachers. Moral dilemmas in one's work are a very sensitive topic, especially in a profession that deals with a human factor. The teachers reflected on their conscience and in fact admitted their moral failures and mistakes. The teachers were also unable to recall all the morally dilemmatic situations in their work, so they sent them to me later. Therefore, the decision to send the questions in advance was a good choice. Some teachers mentioned many morally dilemmatic situations during the interviews; others rather mentioned 
situations that were categorized as stressful. One teacher stated at the beginning of the interview that he had not experienced any morally dilemmatic situations during his seven years of professional practice.

\section{Results}

After conducting all 20 interviews I transcribed them and carried out content analysis with the objective of identifying morally dilemmatic situations (situations that contained a morally dilemmatic choice in themselves). Many of them were not dilemmatic, moral, or ethical. Some of them represented pressure, stress, or frustration, but were not caused by decisions with ethical aspects. The borderline between a dilemma, morality, stress, pressure, frustration, or high demands is very thin. Moreover, this borderline may be subjective to a great extent. I selected 86 situations and gave them to approximately 55 full-time and part-time students with the task of performing an analysis of them and selecting what they considered to be morally dilemmatic situations. I chose this approach in order to avoid my subjective preferences and views.

On the basis of the detailed analysis, cooperation with students, and consultation with academics, I collected 65 professionally morally dilemmatic situations in the teachers' work. These situations were identified by the teachers themselves in their responses.

\section{NeXT STEPS}

On the basis of my research I found out that the situations that were identified may be divided into four categories. In order to establish a validity of the questionnaire, it was important to create categories with similar numbers of items. Some situations that described similar experiences had to be discarded. Some others, on the contrary, had to be made up.

In the next part of the article I will list the categories that were created and their subdimensions. I will state the number of situations in each category and also give examples of the situations.

This category covers morally dilemmatic situations involving the teacher and the management of the school, and includes 17 situations. This category is divided into two subdimensions:

The management of the school is doing something that bothers the teacher, but does not interfere with his competences - includes eight situations.

Required participation in school events cut down the time available for preparation for my teaching.

The management of the school hires unqualified teachers on the basis of mutual friendship.

The management of the school is doing something that bothers the teacher and interferes with his competences - includes nine situations.

The management of the school decides on the disciplinary punishments of my pupils regardless of my opinion. 
The management of the school wants me to change the grades for some pupils, even though I know that the new grade is not appropriate.

The management of the school refuses to let me fail pupils who, in my view, should fail, so the public won't think that the school does not teach well.

This category covers morally dilemmatic situations involving the teacher and his colleagues, which includes 15 situations. This category is divided into three subdimensions:

Colleagues are doing something that bothers the teacher - includes seven situations.

I know that some colleagues do not pay enough attention to the pupils with problems.

I know that some colleagues set a bad example by their behaviour towards their pupils.

Colleagues want something from the teacher that he disagrees with - includes four situations.

My colleague and I have different opinions on the selection of the textbook for the same subject and I conform to his/her requirements, which are in conflict with my conviction.

A colleague demanded a solution of a situation in a manner that was in conflict with my conviction.

The pupils behaved inappropriately towards the teacher's colleague - includes four situations.

The pupils talk about the bad attitude of my colleague.

The pupils slandered my colleague in front of me.
This category covers morally dilemmatic situations involving the teacher and the pupils' parents. This category includes 18 dilemmatic situations. They are divided into three subdimensions:

The influence on the teacher's work of the pupil's parents - includes six situations.

My punishing and rewarding of the pupils are influenced by the reactions of their parents.

My work is influenced by concerns about the negative evaluation of a pupil who is a child of my colleague.

I don't know whether I should organize a school event (trip, theatre, excursion,...) when I have a pupil in my class whose parents do not have enough money for that.

Parents of the pupils behave inappropriately towards their children - includes four situations.

I am forced to cooperate with parents who do not care about their child.

I have to cooperate with parents even though their child-rearing is in conflict with my professional conviction.

Disruption of the teacher's work by a pupil's parent - includes seven situations.

Some parents do homework for their children and expect me to give a positive evaluation of the pupil.

I have to excuse the pupil when helshe has an absence note from his/her parents, even though I know that helshe was not sick and that the parents are covering for him/ her.

The parents of my pupils force me by their demands to retreat from my principles of work. 
This category covers morally dilemmatic situations between the teacher and the conditions of his work (his work content). This category includes 15 situations, which are divided into three subdimensions.

A teacher is doing something that he is not qualified for - includes four situations.

I have to work with pupils with special educational needs even though it is not within my professional competencies.

I do not have enough information for the elaboration of an individual educational plan.

A teacher is doing something that distracts him from teaching - includes five situations.

$I$ have to attend training courses that I do not find beneficial, even though I know they distract me from my pedagogical work.

The unbearable amount of administrative tasks that I have to do is at the expense of my pedagogical work.

I have to participate in projects, even though I know that they distract me from my pedagogical work.

Dissatisfaction of the teacher - includes seven situations.

When I inform OSPOD (the agency for the social-legal protection of children), I have concerns as to whether I will not cause more harm to the pupil.

The reports from the (educational psychology counselling) centre do not take into account information that I provided them with.

One of the first versions also included a fifth category, morally dilemmatic situ- ations between the teacher and society. I found out that these situations could be distributed among the four aforementioned categories.

From these morally dilemmatic situations a questionnaire was subsequently created in which the questions were distributed on the basis of the aforementioned categories. As already noted, the structure of the questionnaire was inspired by the MDS research tool for nurses. At the very beginning of the questionnaire I present the structure of the research tool and the system for its completion to the respondent. I explain to him the concepts of frequency and the level of disturbance, which he is supposed to fill. I also state here the meaning of the numerical values on the Likert scale and what their significance is. I then ask the teachers to react to the situations even if they have never encountered them (reaction to the level of disturbance).

The questionnaire therefore consists of morally dilemmatic situations. Two areas are investigated by using a five-degree Likert scale with a scale from 0 to 4 , where 0 has the lowest value and 4 has the highest value. The first area of investigation is frequency, i.e. how often the teacher encounters the situation. The second area is the level of disturbance, which is measured on a scale from 0 to 4 and signifies the extent to which the situation stresses and disturbs the teacher. At the beginning I ask the teacher to fill in the level of disturbance even if he has never encountered the situation. I ask him to imagine the situation and to put himself in it. The 
objective is to determine the frequency of particular situations and also their significance.

At the very end of the questionnaire there is a space for other situations that the teacher encountered in his work.

Bearing in mind the wide scope and the time load of the questionnaire, I subjected it to qualitative and quantitative feedback, on the basis of which the questionnaire will be reduced and changed.

The questionnaire was subjected to qualitative feedback from 23 teachers working in primary and secondary schools. These teachers differed in terms of their age, the length of their practice, sex, and the types of schools (mainly from the South Bohemia Region and Vysočina Region). The teachers filled in the questionnaire and then made comments on it at the very end either verbally or in writing. I gave them the questionnaire personally and heard out the argumentation and their reactions. I was present during the administration of two questionnaires and heard the comments on each situation.

The biggest problem for the teachers was the length of the research tool. I explained to them that the current form is just a pilot version which, after qualitative and quantitative feedback, will be shortened. Two teachers said that they are not able to even imagine a situation and therefore cannot react to it.

After the qualitative feedback the questionnaire was modified in three aspects. I added a column in which the teacher identifies whether he perceives the situation as morally dilemmatic or not.
The questionnaire was also modified by adding two new situations and by excluding two previous situations. The last thing that was added to the questionnaire was the option $\mathrm{N}$ with regard to moral disturbance. This option is for teachers who are not able to relate to the situation, or do not want to or cannot react to the situation.

I am now focusing on the quantitative research and distributing the questionnaire to teachers in primary and secondary schools in the Czech Republic, in order to verify the functionality of the tool and identify the most frequent and most important situations for determining moral distress.

\section{Discussion}

The topic of moral dilemmas is very difficult. Because of the individuality of each person, his/her unique perception, sensitivity, and other factors, it is difficult to devise a questionnaire that will be suitable for everybody. For these and other reasons, I decided to add to the research tool a column in which the teacher may state whether he considers the situation to be morally dilemmatic or not.

It was surprising for me to hear that one teacher has not encountered any moral dilemma during the seven years of his practice. Many teachers mentioned situations that were directly related to the pupil but did not in themselves contain any moral dilemma or choice.

It follows from the 20 interviews with teachers from primary and secondary 
schools that the areas in which moral dilemmas occur in the teaching profession do not differ from the areas in the medical environment. Teachers feel the moral dilemmas especially in their work relations. These relations are between the teacher and his colleagues, the management of the school, and the parents of his pupils, and also involve the conditions of their work, which are constituted primarily by the education policy. Nurses experience professional moral dilemmas in relation to their clients, superiors, clients' families, colleagues, and society.

The fact that there is no category of moral dilemmas with a direct relation to the pupil can easily be explained. Nearly all of the above-mentioned morally dilemmatic situations relate to the clients, i.e. the pupils, and to the concern felt by the teachers about their professional upbringing and education, which are limited precisely by the aforementioned interventions. The fact is that the situations mentioned by the teachers themselves focus primarily on the pupil.

\section{Conclusion}

The topic of moral distress is important and brand new. It turned out that the questionnaire for healthcare professionals was of limited value as inspiration for creating a research tool for the teachers' environment. Therefore, I decided to create a research tool from scratch. I used in-depth interviews with teachers to identify a set of moral dilemmas. These dilemmas were subsequently evaluated by students - future teachers. The qualitative feedback showed that this problematic is very sensitive, and the perception is rather subjective. Therefore, I added a column to the questionnaire that allows respondents not to express their opinion and also to problematize the situation as not morally dilemmatic. The objective was to make responding as comfortable as possible. These changes were a modification of the previous version of the questionnaire for the medical environment. In the next steps of my research I will give the research tool (questionnaire) to selected groups of teachers from primary and secondary schools in the Czech Republic in order to verify the functionality of the tool.

Moral distress, or professional morally dilemmatic situations in teachers' work, is a very sensitive and not very well-known area in the teaching profession. However, it is a very important topic. Teachers themselves usually do not speak about these topics because of their sensitivity and difficulty. But the pressure that they experience in their work may be the cause of burnout and of their quitting the teaching profession. My research suggests that that there are many situations in which teachers experience a moral dilemma. These dilemmas are primarily related to the relations between people, namely between the teacher and his pupils and especially to the relation of the teacher to himself. Ignoring these feelings among teachers may even lead to the transformation of the whole system of education. 
If the moral distress were discovered, psychologists and therapists could then help these teachers. The morally dilemmatic situations that were identified may also be used as examples and for preven- tion. If these situations were highlighted and competent people were able to find the solutions during the education of future teachers, then teachers would know how to act in these situations.

\section{REFERENCES}

Almeida, H. (2013). A longitudinal study about stress, burnout and coping. International Journal of Human Resource Studies, 3(2), 109-125.

Corley, M. (2002). Nurse moral distress: a proposed theory and research agenda. Nursing Ethics, 9(6), 636-650.

Crane, M. F., Bayl-Smith, P., \& Cartmill, J. (2013). A recommendation for expanding the definition of moral distress experienced in the workplace. Australian and New Zealand Journal of Organisational Psychology, 6(1), 1-9.

Cranston, N., Ehrich, L. C., \& Kimber, M. (2006). Ethical dilemmas: the "bread and butter" of educational leaders' lives. Journal of Educational Administration. 44(2), 106-121.

Etzioni, A. (Ed.). (1969). The semi-professions and their organization. London: The Free Press. Hargreaves, E. A. (2000). Four ages of professionalism and professional learning. Teaching and Teacher Education, 6(2), 151-182.

Helus, Z., \& Lukášová, H. (2012). Promèny pojetí vzdèláváni a školního hodnoceni: filozofická východiska a pedagogické souvislosti [Transformations of the conception of education and of the school evaluation: philosophical premises and pedagogical context]. Praha: Asociace waldorfských škol ČR.

Huberman, A. M. (1978). L'evolution de la formation americaine. Une analyse contextuelle de la formation des enseignants aux Etats-Unis et quelques points de comparaison avec Europe francophone. In M. Debesse \& G. Mialaret (Eds.), Traite des sciences pedagogiques. Tome 7: Fonction et Formation des Enseignants (pp. 315-340). Paris: PUF.

Jameton, A. (1993). Dilemmas of moral distress: moral responsibility and nursing practice. AWHONN's Clinical Issues in Perinatal and Women's heaLth Nursing, 4(4), $542-551$.

Janík, T. (2013). Od reformy kurikula k produktivní kultuře vyučování a učení [From the curriculum reform to a productive culture of teaching and learning]. Pedagogická orientace, 23(5), 634-663.

Mareš, J. (2017a). Morální distres školních psychologů [Moral distress of school psychologists]. Pedagogická orientace, 27(2), 308-343.

Mareš, J. (2017b). Morální distres učitelů - skrytý problém [Moral distress of teachers - a hidden problem]. Pedagogika, 67(1), 27-55.

Straková, J. (2007). Kurikulární reforma z pohledu šetření Kalibro [Curriculum reform from the perspective of the Kalibro research]. Pedagogika, 57(1), 21-36. 
Štech, S. (2008). Profese učitele [The teaching profession]. In S. Bendl \& A. Kucharská (Eds.), Kapitoly ze školni pedagogiky a školni psychologie: skripta pro studenty vykonávajicí pedagogickou praxi (pp. 139-144). Prague: Charles University, Faculty of Education.

Vašutová, J. (2004). Profese učitele v českém vzdèlávacím kontextu [The teacher's profession in the Czech educational context]. Brno: Paido.

Váchová, M. (2017). Inkluzivni vzdèláváni z pohledu učitelù na vybraných základních školách $v$ České republice [Inclusive education from the perspective of teachers in selected basic schools in the Czech Republic]. (Bachelor's thesis.) České Budějovice: University of South Bohemia, Faculty of Health and Social Sciences.

Webster, G., \& Baylis, F. (2000). Moral residue. In S. B. Rubin \& L. Zoloth (Eds.), Margin of error: The ethics of mistakes in the practice of medicine (pp. 217-232). Hagerstown: University Publishing Group.

Mgr. Markéta Váchová

Charles University, Faculty of Education, Institute for Research and Development of Education; e-mail: MarkytkaVachova@seznam.cz 